\title{
Advanced Lithium Secondary Batteries Using Tin-Iron Alloy Negative Electrodes Prepared by Electroplating
}

\author{
Tsukasa SONODA, ${ }^{\text {* }}$ Hironori KOBAYASHI, ${ }^{\mathrm{b}}$ Kenichi KOMOTO, ${ }^{\mathrm{b}}$ \\ Hikari SAKAEBE, ${ }^{\mathrm{b}}$ and Kuniaki TATSUMI ${ }^{\mathrm{b}}$
}

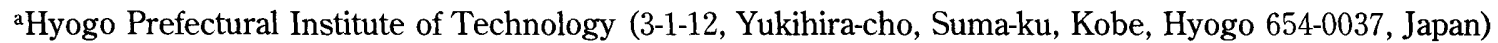

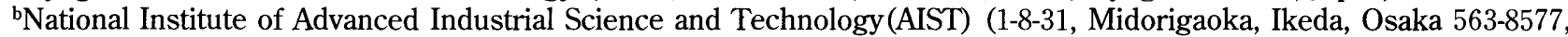
Japan)
\end{abstract}

Received May 30, 2003 ; Accepted August 20, 2003

\begin{abstract}
The charge-discharge behaviour of tin-iron ( $13 \%$ by weight) alloy films plated on rolled copper foils was investigated. X-ray diffraction patterns of the tin-iron alloy films contained peaks corresponding to $\mathrm{FeSn}_{2}$ and tin. This negative electrode possessed a discharge capacity of $356 \mathrm{mAh} / \mathrm{g}$ after 50 cycles using metallic lithium as the counter electrode and was superior to tin-plated copper and carbon negative electrodes. These results suggest that the dispersion of iron in tin deposits separated from the tin-iron alloy during the first charge reaction improves the electrical conductivity between regions of tin-lithium intermetallic compounds formed during discharge and leads to the suppression of repeated contraction and expansion of the plated film.
\end{abstract}

Key Words : Tin-Iron Alloy Plating, Lithium Secondary Battery, Negative Electrode, Electroplating

\section{Introduction}

Lithium secondary batteries have become widely used due to their high energy density, which is important in devices such as notebook-type personal computers and mobile telephones. However, it is necessary to further enhance the energy density due to the increase in communication by photographs and animation in mobile telephones and for the realization of environmentally friendly electric cars.

Although metallic lithium (with a theoretical discharge capacity of $3860 \mathrm{mAh} / \mathrm{g}$ ) would have the highest capacity of any lithium secondary battery negative electrode, it presents an obvious danger due to flammability.

Tin (with a theoretical capacity of $994 \mathrm{mAh} / \mathrm{g}$ ) has not only a capacity of approximately 2.7 times that of carbon negative electrodes (theoretical capacity $372 \mathrm{mAh} / \mathrm{g}$ ) in terms of unit weight and 8.9 times that of carbon in terms of unit volume, but tin negative electrodes also have the advantage of being cheap to fabricate. In the tin plating method a conductive material and binder are unnecessary, and tin has excellent adhesion properties on copper foils. ${ }^{1-4)}$ It has been found that the chargedischarge cyclability of tin alloy-plated films ${ }^{5)}$ is superior to that of tin-plated films. The charge-discharge behaviours of tin-plated films with heat-treatment ${ }^{6,7)}$ and of tin-silver and tin-antimony alloy films ${ }^{8)}$ have also been reported. In this study, the charge-discharge cyclability of coin-type cells containing tin-iron alloy-plated negative electrodes is compared to that of tin-plated and carbon negative electrodes.

\section{Experimental}

2. 1 Preparation of tin-iron alloy-plated negative electrodes

Tin-iron alloy films of approximately $3 \mu \mathrm{m}$ thickness were deposited on one side of rolled copper foils of 18 $\mu \mathrm{m}$ thickness by the electroplating method for negative electrodes. Electroplating was carried out at a current density of $10 \mathrm{~mA} / \mathrm{cm}^{2}$ using a bath containing $0.1 \mathrm{~mol} /$ $\mathrm{dm}^{3} \mathrm{SnSO}_{4}, 0.05 \mathrm{~mol} / \mathrm{dm}^{3} \mathrm{FeSO}_{4}, 0.3 \mathrm{~mol} / \mathrm{dm}^{3}$ sodium gluconate and $1 \mathrm{~g} / \mathrm{dm}^{3}$ polyethyleneglycol. The bath was adjusted to $\mathrm{pH} 4$ and was maintained at a temperature of $35^{\circ} \mathrm{C}$. A neutral gluconate bath ${ }^{2)}$ was used for bright tin plating. The iron content of the plating films was analyzed by the energy dispersive X-ray analysis technique, and the surface morphology was observed using scanning electron microscopy. The crystal structure of the plating film was examined using X-ray diffraction $(\mathrm{Cu} \mathrm{K} \alpha$ radiation, diffractometer operated at $40 \mathrm{kV}$ and $20 \mathrm{~mA}$ ).

2. 2 Preparation of positive electrode and carbon negative electrode

To prepare the positive electrode, $\mathrm{LiCoO}_{2}, \mathrm{PVdF}$ and acetylene black were mixed in the ratio $86: 10: 4$. A solvent (NMP) was added to form a slurry, which was coated on aluminium foils and dried at $150^{\circ} \mathrm{C}$ before pressing to a thickness of $85 \mu \mathrm{m}$. The compressed foils were then dried under vacuum for $12 \mathrm{~h}$ at a temperature of $120^{\circ} \mathrm{C}$. The carbon negative electrode was prepared in similar fashion. A mixture of meso-carbon microbeads and PVDF in the ratio $90.5: 9.5$ was prepared, then coated on rolled copper foils, dried at $150^{\circ} \mathrm{C}$ and pressed to a thickness of $60 \mu \mathrm{m}$ before being dried at $100^{\circ} \mathrm{C}$ for $20 \mathrm{~h}$ under vacuum. 


\section{3 Preparation of coin cells and charge-discharge test}

Coin-type cells (CR2032) were assembled using counter electrodes either of metallic lithium (foils of thickness $1 \mathrm{~mm}$ and diameter $14 \mathrm{~mm}$ ) or $\mathrm{LiCoO}_{2}$ (prepared as described above) and with $1 \mathrm{~mol} / \mathrm{dm}^{3}$ $\mathrm{LiN}\left(\mathrm{CF}_{3} \mathrm{SO}_{2}\right)_{2} / \mathrm{EC}+\mathrm{DEC}(1: 1) \quad$ electrolyte. Chargedischarge tests versus $\mathrm{Li} / \mathrm{Li}^{+}$, using metallic lithium as the counter electrode, were carried out in a constant temperature oven at $25^{\circ} \mathrm{C}$ over the voltage range $0-1 \mathrm{~V}$. The coin-type cells were also tested under the condition that the charge capacity of the tin-iron (13 wt $\%$ ) alloyplated negative electrode was set to $300 \mathrm{mAh} / \mathrm{g}$, with the lower limit of the voltage during discharge at $3 \mathrm{~V}$. The total capacity of the $\mathrm{LiCoO}_{2}$ positive electrode was greater than that of the negative electrode at this charge capacity.

\section{Results and Discussion}

The appearance of the tin-iron alloy films plated on rolled copper foils was smooth and lustrous, and the iron content of the films was found to be $13 \%$ by weight. A representative X-ray diffraction pattern of these films is shown in Fig. 1. The diffraction peaks correspond to $\mathrm{FeSn}_{2}$ and tin.

Figure 2 shows the results of the charge-discharge tests for the tin-plated negative electrode (film thickness $2 \mu \mathrm{m}$ ), the tin-iron alloy-plated negative electrode (film thickness $3 \mu \mathrm{m}$ ) and the carbon negative electrode, using metallic lithium as the counter electrode. In the first cycle the charge-discharge test was carried out using a current density of $0.1 \mathrm{~mA} / \mathrm{cm}^{2}$, which was increased to $0.2 \mathrm{~mA} / \mathrm{cm}^{2}$ after the second cycle. The discharge capacity of the tin-plated negative electrode rapidly decreased over the first 10 cycles, falling to a value of approximately $200 \mathrm{mAh} / \mathrm{g}$ after 50 cycles. In contrast, the capacity of the carbon negative electrode was almost constant, with a value of $262 \mathrm{mAh} / \mathrm{g}$ after 50 cycles. However, the highest capacity, with a value greater than $400 \mathrm{mAh} / \mathrm{g}$ over the first 40 cycles, was achieved for the tin-iron

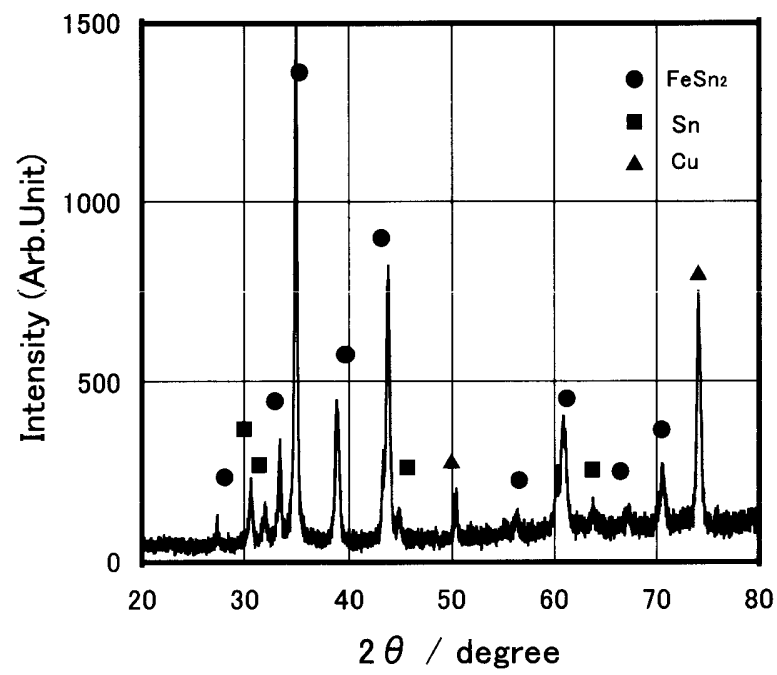

Fig. 1 X-ray diffraction pattern of tin-iron (13 wt $\%$ ) alloyplated film.

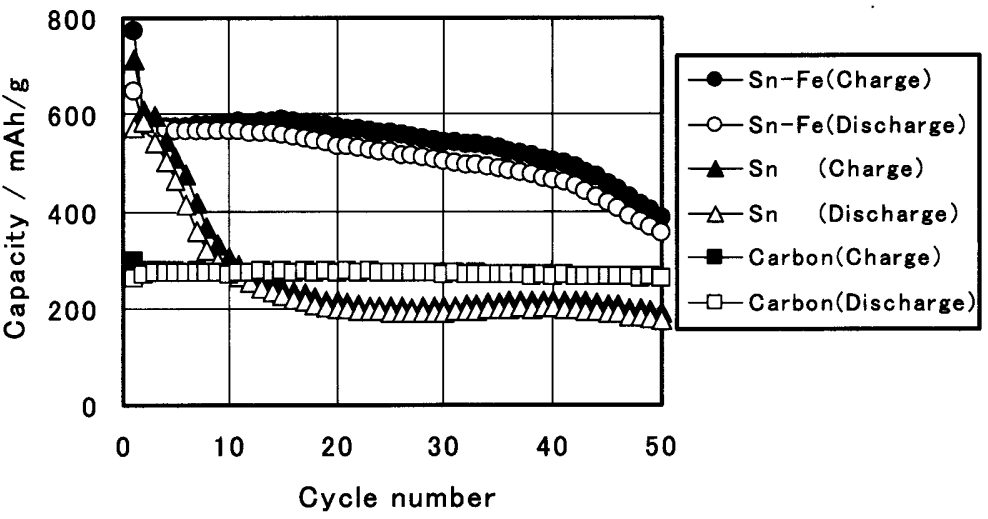

Fig. 2 Effect of number of cycles on discharge capacity of carbon, tin-plated and tin-iron $(13 \mathrm{wt} \%)$ alloy-plated negative electrodes.

alloy-plated negative electrode; the discharge capacity remained above $350 \mathrm{mAh} / \mathrm{g}$ after 50 cycles. It is clear that the charge-discharge behaviour of the tin-iron alloyplated negative electrode is greatly superior to the tinplated and carbon negative electrodes.

The charge-discharge capacity of the tin-plated negative electrode rapidly decreases due to the formation of compounds such as $\mathrm{Li}_{22} \mathrm{Sn}_{5}$ through the charge-discharge reaction of tin and metallic lithium. This leads to repeated contraction and expansion of the film, and the electrical conductivity in regions of the film consisting of tin-lithium intermetallic compounds is believed to decrease rapidly. In the tin-iron alloy-plated film, the charge-discharge process is thought to result in the deposition of iron in regions of the film where a tin matrix is present in the initial cycle, following the formula below.

$$
44 \mathrm{Li}^{+}+44 \mathrm{e}^{-}+5 \mathrm{FeSn}_{2} \longrightarrow 2 \mathrm{Li}_{22} \mathrm{Sn}_{5}+5 \mathrm{Fe}
$$

This mechanism also was proposed by $\mathrm{Ou}$ Mao et $a l,{ }^{9,10)}$ who studied the charge-discharge behaviour of an negative electrode made from a tin-iron alloy powder by the mechanical alloying method. The repeated contraction and expansion of the tin-iron alloy-plated film is thought to be suppressed by the enhancement of electrical conductivity between regions rich in tin-lithium compounds.

Figure 3 shows the results of the charge-discharge test for a coin cell consisting of a tin-iron plated negative electrode and a $\mathrm{LiCoO}_{2}$ positive electrode. The chargedischarge test for the coin cell was carried out at a charge and discharge rate of $1 / 40 \mathrm{C}$ during the first cycle, and at $1 / 10 \mathrm{C}$ (charging) and $1 / 5 \mathrm{C}$ (discharging) after the second cycle. Although the initial efficiency was $71.9 \%$, the cell showed a charge-discharge efficiency of more than $95 \%$ after the third cycle. When the charge capacity was set to $300 \mathrm{mAh} / \mathrm{g}$, the cell possessed a discharge capacity of $283 \mathrm{mAh} / \mathrm{g}$ after 100 cycles. From these results it can be concluded that tin-iron alloy-plated films can be applied as high capacity negative electrodes for advanced lithium secondary batteries. 


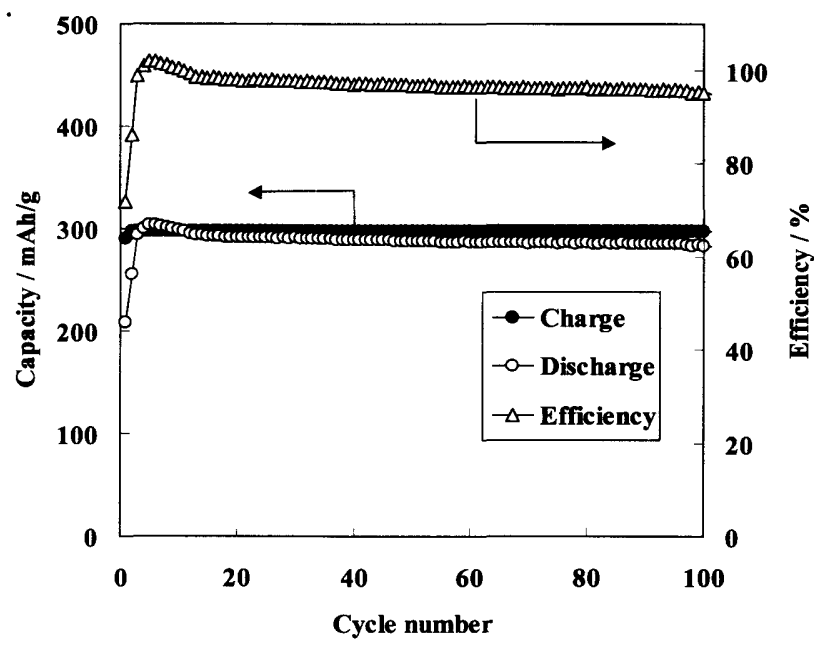

Fig. 3 Effect of number of cycles on discharge capacity of coin-type cell containing a tin-iron (13 wt $\%$ ) alloy-plated negative electrode and a $\mathrm{LiCoO}_{2}$ positive electrode.

\section{Conclusions}

Charge-discharge tests were carried out after assembling coin-type cells containing tin(13 wt \%)-iron alloyplated films deposited on the surface of rolled copper foils as the negative electrode. After 50 cycles this cell showed a discharge capacity of greater than $350 \mathrm{mAh} / \mathrm{g}$. The improvement in cyclability of this tin-iron alloy negative electrode is thought to be due to the enhancement of electrical conductivity between regions of the film con- taining tin-lithium compounds formed on discharge and the suppression of repeated contraction and expansion of the negative electrode by the dispersion of iron particles in tin deposits formed during the initial charge-discharge reaction.

\section{References}

1) T. Sonoda, S. Wakisaka, T. Fujieda, M.Shikano, and T. Sakai, The 99th proceedings of Surface Finishing Society of Japan, p.114 (1999).

2) T. Sonoda, T. Fujieda, M. Shikano, and T. Sakai, Japanese Patent Publication 2001-68094.

3) T. Sonoda, H. Kobayashi, K. Komoto, H. Sakaebe, and T. Sakai, The 42nd battery symposium, p.284 (2001).

4) T. Sonoda, T. Fujieda, and T. Sakai, Japanese Patent Publication 2002-198091.

5) T. Sonoda, Denchi Gijutsu, 14, 14 (2002).

6) R. Ohshita, N. Tamura, M. Kamino, M. Fujimoto, S. Fujitani, and I. Yonezu, The 67th Electrochemistry symposium, p.170 (2000).

7) S. Kitamura, D. H. Kim, M. Yoshimoto, K. Obata, T. Sonoda, and T. Sakai, The 42nd battery symposium, p.288 (2001).

8) J. O. Besenhard, J. Yang, and M. Winter, J. Power Sources, 68, 87 (1997)

9) Ou Mao, R. A. Dunlap, and J. R. Dahn, J. Electrochem. Soc., 146, 405 (1999).

10) Ou Mao and J. R. Dahn, J. Electrochem. Soc., 146, 414 (1999). 